\title{
The Effectiveness Of The Implementation Of Experiences Framework, Language, Pictures, Symbols, And Application (ELPSA) Cooperative Setting Of Students Teams Achievemet Division (STAD) Type In Mathematics Subjects On Set Material Of Grade VII at SMPN 29 In Bulukumba
}

\author{
Dwinto Reskiawan ${ }^{1)}$ \\ ${ }^{1}$ SMP Negeri 29 Bulukumba, Kabupaten Bulukumba \\ e-mail: ekimathunm@gmail.com ${ }^{1}$ Contact: 085255704310
}

\begin{abstract}
The research aimed at describing the Effectiveness of Experiences, Language, Picture, Symbols, and Application (ELPSA) on Cooperative Setting of Students Teams Achievement Division (STAD) Type in Mathematics Subjects on class X SMP Negeri 29 Bulukumba. The populations of this research were all students of grade class X SMP Negeri 29 Bulukumba and choose one class as the sample of the research by using simple random sampling as the experiment class, clas VII A, was given the treatment of Experiences, Language, Picture, Symbol, and Apllication (ELPSA) Cooperative Setting on STAD type. The data collections consisted of the data of learning model implementation, data of students' activities, in learning process, data of students' response on learning instruments, and data of students' learning result which consisted of the pretest and posttest scores. The data of learning model implementation, students' activities, and students' response data were analyzed by using statistic descriptive analysis; whereas, mathematics learning result os students was analyzed by employing statistics descriptive and statistics inferential analysis. The results of the research revealed that (1) the average score of learning implementation level (TKP) was in good criteria $(3.50 \leq \mathrm{x} \leq 4.50)$ which was 3.17 ; (2) the average score of students' activity had met sufficiently active criteria $(2.5$ - 3.4) which was 2.87 ; (3) students' responds is in positive category $(3.50-4.0)$ which was 3.51 ; (4) the everage of students' learning result before the treatment was in very low category $(0-54)$ which was 31.37 from the ideal score 100. The everage of students' learning result after the treatment was in high category (80-89) which was 81.68 from the ideal score of 100 . The everage of students' improvement score (gain value) was in high category $(x \geq 0.7)$ which was 0,73 . Based on inferential statistic analysis on students' learning result after the treatment, it was obtained $\mathrm{P}$-value $<\alpha(0.01<0.05)$ so $\mathrm{H}_{0}$ was rejected and $\mathrm{H}_{1}$ was accepted where the everage of students' learning result was higher than $74.9(\mathrm{KKM})$, and the everage of students' learning improvement score (gain value) obtained $\mathrm{P}$-value $<\alpha$ $(0.01<0.05)$, so $\mathrm{H}_{0}$ was rejected and $\mathrm{H}_{1}$ was accepted where the everage of students improvement score (gain value) was higher than 0.29. Based on the results of the analysis of the level of holistic learning effectiveness concluded that the implementation of Experiences, Language, Picture, Symbol, and Apllication (ELPSA) on Cooperative Setting of Students Teams Achievement Division (STAD) Type is quite effective to be implemented in Mathematics subjects on class X SMP Negeri 29 Bulukumba.
\end{abstract}

Keywords: Effectivenes, ELPSA, STAD

\section{INTRODUCTION}

Learning mathematics there is a need for students activity in working on existing problems, not just receive of knowledge from the teacher. In this case, the teacher should act as a guide , mediator, and facilitator.

Learning of mathematics which is meaningless and only limited to memorizing formulas and allow students to work on problems, students reasoning 
becomes less developed which results in students understanding of the concept of mathematical material is very weak and lack of enthusiasm for student to learn. So many students still think that mathematics are a boring and difficult subject. Students often assume that mathematics lessons will not be useful in the future and become aburden for students because they have abstraction objects and the language used is more in the form of symbols full of numbers and formulas.

This assumption can affect students' mentality and can also lead to negative attitudes of students towards learning mathematics, the effect is students become lazy to take mathematics.

The indication can be seen from the student learning outcomes that are less satisfactory. The results of Thrends International Mathematics Science Study (TIMSS) in 2011 showed that Indonesian students' understanding of mathematics was ranked 38 out of 42 countries. Based on the fact above it can be seen that the average ability of Indonesian students in mathematics is still lack. In fact, we are far behind compared to other ASEAN countries such as Singapore, Thailand and Malaysia, " One of the contributing factors is that most students only memorize the formula to solve mathematical problems, do not understand the mathematical concepts, learning in class is less dynamic, does not make students think creatively, the material taught is far from the real-world context and teaching material is not associated with student experience. This fact, make students become bored learning mathematics. Therefore, it is necessary to strengthen the role of mathematics and mathematics education, especially the quality of the instructors. Every mathematics teacher neeed be given training and an introduction to good and correct learning methods. This was conveyed in a national seminar on mathematics and mathematics education at UNY by Faculty of Mathematics and Natural Sciences UII on November 10, 2013 (Ratih, 2013)

Efforts to improve the quality of mathematics learning in schools continue to be done both in understanding the material, learning approaches and learning methods. In connection with the teaching of mathematics Soedjadi (Rahmawati, 2012 ) states that "however good the curriculum is, however good the mathematical material to be determined is impossible to achieve educational goals if not through a suitable learning process".

One of the schools that had been observed as stated previously, namely SMP Negeri 29 Bulukumba. This school is a school located in Bontotiro District, Bulukumba Regency. Based on the results of observations and interviews with mathematics subject teachers, it was obtained that students still had difficulty in understanding mathematics lessons which resulted in the low average mathematics learning outcomes at class $\mathrm{X}$ students, this can be seen from the results of the odd semester semester 2015/2016 Academic Year,namely the average student learning outcomes only reached 59 of the ideal score of 100 and the level of KKM learning only reached $54,5 \%$, KKM of mathematics subject was 75 and completeness was approximately $80 \%$ ). 
Furthermore, regarding the application of learning obtained information that teachers carried out conventional learning by using direct teaching, here the learning process was dominated by teachers who actively explained the material while students were actively listening and taking notes even though teachers were required to be able to apply learning based on the specific material being taught.

Researchers also conducted interviews and followed-up observations of mathematics teachers who tought at SMP Negeri 29 Bulukumba, and obtained information that when the learning process took place only certain students were dominant in learning, a few students were daydreaming, silent, even some students were not excited in following learning. Another problem when the teacher explained a number of examples of questions students used to understand with the teacher's explanation, but when they were given a question of practice students always found it difficult to solve the problem. This indicated that they had not fully understood the concept of the material being studied. Students only memorized the solution based on the formula that had been explained by the teacher. Considering from the process of learning, it was indicated that teachers were still not able to optimize student experience to build a holistic understanding of set concepts, because the teacher transferring knowledge directly. According to Freudenthal (Ibrahim and Suparni. 2008: 10) that when children learn mathematics in an isolated way, less experienced reality, it will be quickly forgotten and they will not be able to apply it.

The conclusion that could be drawn from the observations above was the low learning outcomes caused by students understanding on the concepts of the material were less, the materials were less attracted on students' view, and student involvement in learning was limited, including in terms of asking questions. Therefore, students could not find their own concepts. Moreover, the mathematics teaching in the classroom was dominated by lecture, influenced by textbooks (mostly symbolic), and the materials were less associated with life or experience of student so that students were not able to construct their own knowledge .

Related to the level of intellectual development of junior high school students who were still less in implementation, it was necessary to create a problem situation that was truly contextual or based on the experience of students, so that students could solve problems in informal ways. This was in line with the framework of learning: Experiences, Language, Pictures, Symbol, and Application (ELPSA). Liebeck in (Lowrie \& Patahudin, 2015: 94), mathematics is an abstraction from reality where in the process of abstraction, a sequence of special events occurs in the formation of concepts that lead to understanding. In the model, $\mathrm{E}$ is as (experience), $\mathrm{L}$ is as (language), $\mathrm{P}$ is as ( Pictures), and $\mathrm{S}$ is as (symbols) Tom Lowrie and Sitti Maesuri Patahuddin expand this stage by adding elements of application.

ELPSA with elements of Experience, Language, Picture, Symbol, and Application are based on theories of constructivism learning and social nature. The ELPSA framework sees learning as an active process in which students construct their own way of understanding things through the process of thinking individually and interacting with others. However, it is important to 
remember that ELPSA is not a linear process. Learning is a complex process that cannot be fully predicted and does not occur in a linear sequence. Thus the ELPSA elements can be thought of as interconnected and complementary elements.

The ELPSA framework is based on the assumption that experience (both personal and social) is the foundation for the introduction of new learning opportunities. The social dimension to this component of experience is very important. Some education experts emphasize the same thing (Cobb, 1988; Lave \& Wenger, 1991; Lerman, 2003; Wenger, 1999) in (Lowrie \& Patahuddin, 2015: 96) . The main idea of social theory is based on the statement that learning occurs from the participation or active involvement of students. Freudenthal (Gravemeijer, 2010:2) indicates that the safeguarding of the concept is meaningful if it is built and linked to one's life experience or the opportunity for involvement with one another. That is, teaching practice allows students to develop mathematical ideas that are related to their personal experience or initial knowledge, as well as to be involved in group discussions.

The learning process will also run smoothly, the difficulties and concepts that are poorly understood will be more resolved while the classmates are discussing their partners. Therefore it is necessary to apply various methods, strategies and models in mathematics learning, so students do not consider mathematics as something to fear because mathematics is actually interesting and very close to real life.

One model of learning that is expected to be better than conventional learning that is expected to be able to overcome the above is cooperative learning. According to Trianto (2011: 41) cooperative learning is learning that arises from the concept that students will find it easier to find and understand difficult concepts if they discuss with each other. Students routinely work in groups to help each other solve complex problems.

Cooperative learning can provide opportunities for students to actively learn in an atmosphere of democracy, so students can learn mathematics with pleasure and be able to operate their brains to the maximum to absorb the knowledge provided by the teacher as well as from the learning environment. Cooperative learning allows teachers to pay attention to students so that a more intimate relationship can be established between teacher and student as well as between student and student.

One type of cooperative learning is the Cooperative Student Teams Achievement Division (STAD) Type. In STAD type cooperative learning requires maximum student readiness to understand the problem given by the teacher and be able to explain the solution of the problem. Each group member has the same opportunity to explain the solution of the problem given by the teacher, this requires each group to prepare all members optimally. This will make students interact and discuss in groups to find the right solution of the problems given by the teacher. Thus, cooperative learning type STAD can emphasize a deep understanding of the concept, in turn, can improve student learning outcomes. 
The ELPSA learning framework can be implemented by forming small groups in learning. This reminds us of the characteristics of cooperative learning which emphasizes group collaboration. This condition gives meaning that the ELPSA learning framework can be implemented cooperatively. This means that the ELPSA learning framework can be combined with STAD type cooperative learning. Thus in this study, researchers applied the ELPSA learning framework with a STAD cooperative type.

The application of the ELPSA learning framework STAD type cooperative settings can provide opportunities for broader cognitive exploration to students so that in its application can increase creativity in building their own knowledge which turn students understand the material more intact. This can happen through group membership in cooperative STAD heterogeneous types, both in terms of abilities and other characteristics, it will be able to benefit students who are low or moderate. Conversely, students who are highly capable of making verbal communication skills in mathematics will increase. Because to provide an explanation of a mathematical material or problem given to the group a student must understand the material deeper than just the ability needed to produce an answer on a worksheet. Likewise, the ELPSA learning framework that links teaching material with student experience as a starting point for learning can attract students' attention to learning because students learn through what they already know. The combination of the ELPSA learning framework, STAD cooperative type will have a better effect on student learning outcomes, considering that the application of the ELPSA learning framework STAD cooperative type are considered capable of optimizing the role of students in learning both physically and psychologically.

Based on the description above, it appears that the application of ELPSA learning framework STAD cooperative can improve the understanding of concepts of mathematical material especially the set of materials and can create an effective and pleasant learning atmosphere for students. Thus the application of the ELPSA learning framework, STAD type cooperative settings can be the solution of problems in learning mathematics in class X SMP Negeri 29 Bulukumba.

Based on the description in the above background, the formulation of research questios were: 1) How would the learning outcomes of Seventh Grade Students of SMP Negeri 29 Bulukumba taught through Experiences, Language, Pictures, Symbol And Application (ELPSA) Framework, Student Teams Achievement Division (STAD) Cooperative Type in the Mathematics Learning? 2) How does the activity of Seventh Grade Students of SMP Negeri 29 Bulukumba taught through Experience, Language, Picture, Symbol and Application (ELPSA) Framework, Type Student Teams Achievement Division (STAD) Cooperative Cooperative in mathematics learning materials ? 3) How is the response of class X SMP Negeri 29 Bulukumba taught through Experience, Language, Picture, Symbol and Application (ELPSA) Framework Student Teams Achievement Division (STAD) Cooperative Type in Mathematics Learning materials ?4) Is the application of Experience, Language, Pictures, Symbol s and Application (ELPSA) Framework, 
Student Teams Achievement Division (STAD) Cooperative Type effective in the application of mathematics learning materials on class X SMP Negeri 29 Bulukumba?

\section{METHOD OF RESEARCH}

This type of research is a pre-experimental research design. It is stated as pre-experimental research design, because this design is not an actual experiment. Because there are still outside variables that influence the formation of the dependent variable. This study was to determine the effectiveness of the application of the Experiences, Language, Pictures, Symbols and Application (ELPSA) framework of the Student Teams Achievement Division (STAD) cooperative type in the mathematics learning of set material.

Variables wereconcepts that have a value variation. There were two types of variables in this study, namely the independent variable and the dependent variable. The independent variable in this research was the ELPSA framework of STAD cooperative type while the dependent variable in this research was the student learning outcomes, student activities, and student responses.

The research design was the One-Group Pretest-Posttest Design . The design can be seen in the table below:

Tabel 3.1. One-Group Pretest-Posttest Design

\begin{tabular}{ccc}
\hline Pretest & Treatment & Posttest \\
\hline $\mathrm{O}_{1}$ & $\mathrm{X}$ & $\mathrm{O}_{2}$ \\
\hline & Sugiyono $(2013)$ &
\end{tabular}

Sugiyono (2013).

Note : $\mathrm{X}$ : Treatment, $\mathrm{O}_{1}$ : Pretest value (before treatment), and $\mathrm{O}_{2}:$ Posttest value (after treatment)

The experimental units in this research were all students of class X SMP Negeri 29 Bulukumba in the 2015-2016 school year consisted of 95 students and spreaded in 4 parallel classes, namely VII-1, VII-2, VII-3, VII-4. By using the Simple Random Sampling technique, which is a random sampling technique without regard to strata in the population, class VII-I was selected, amounted to 22 students, to be the research sample. The selected experimental class was the experimental unit.

The instrument used in this research was a test of learning outcomes as a measure of students' mathematical abilities, observation sheets of learning model implementation, observation sheets of student activities, and student questionnaire responses to learning.

Data analysis techniques used in quantitative research are directed to answer the problem formulation or test hypotheses that have been formulated, because the data are quantitative then the data analysis technique uses statistical methods, (Sugiyono 2013: 333). Inferential statistical analysis was used to analyze data specifically. Inferential statistics are statistical techniques used to analyze sample data and the results are applied to populations. Inferential 
statistical analysis is used to test the hypothesis of effective criteria using paired ttests, with the criterion $\mathrm{H}_{1}$ accepted if $>$ or if $\mathrm{p}<\alpha$ and if $\mathrm{p} \geq \alpha$, then

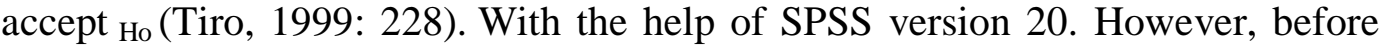
testing the hypothesis, a normality and homogeneity test was firstly conducted.

\section{RESEARCH RESULT AND DISCUSSION}

\section{Descriptive Analysis Result}

Descriptive analysis aimed to describe the variation of the data collected through research instrument in the experimental class taught by Experiences, Language, Pictures, Symbols and Application (ELPSA) Cooperative Type, Student Teams Achievement Division (STAD). The data to be analyzed were data about the activities of teachers managing learning, student learning outcomes in mathematics, data on student activity in learning, and data on student responses to learning and learning devices.

a. Teacher Activities in Experiences, Language, Pictures, Symbols and Application (ELPSA) Frameworks for Cooperative Type, Student Teams Achievement Division (STAD)

The results of observations of the feasibility of the learning model in the learning process can be seen in the following table:

Tabel 4.8. Observation Results on the Implementation of ELPSA Framework Cooperative Type STAD in learning mathematics on grade VII students of SMP Negeri 29 Bulukumba

\begin{tabular}{lccc}
\hline \multicolumn{1}{c}{ Observed aspects } & $\begin{array}{c}\text { Average score } \\
\text { of meetings IV }\end{array}$ & Criteria & Criteria Description \\
\hline $\begin{array}{l}\text { Core activities } \\
\begin{array}{l}\text { End activities } \\
\text { Time Management }\end{array}\end{array}$ & 3.86 & Well done & $\begin{array}{l}3,50<\bar{x} \leq 4,50 \\
3,50<\bar{x} \leq 4,50\end{array}$ \\
$\begin{array}{l}\text { and Observation of } \\
\text { Classroom }\end{array}$ & 3.63 & Well done & $3,50<\bar{x} \leq 4,50$ \\
$\begin{array}{l}\text { Atmosphere } \\
\quad \text { Average }\end{array}$ & 3.80 & Well done & $3,50<\bar{x} \leq 4,50$ \\
& $\mathbf{3 , 7 1}$ & Well done & $\mathbf{3 , 5 0}<\overline{\boldsymbol{x}} \leq \mathbf{4}, \mathbf{5 0}$
\end{tabular}

b. Student Activities through the Application of Experiences, Language, Pictures, Symbols and Application (ELPSA) Framework Cooperative Type, Student Teams Achievement Division (STAD)

The following data are the results of categorizing student activities presented in the following table: 
Tabel 4.9. Categorical Average Scores of Student Activity From Two Observers.

Activity Aspects

\begin{tabular}{lccc} 
& & & Meeting \\
1 & I & II & III \\
2 & 1.95 & 2.35 & 3.10 \\
3 & 2.20 & 2.30 & 2.80 \\
4 & 2.70 & 3.00 & 3.20 \\
5 & 2.00 & 2.25 & 2.55 \\
6 & 3.05 & 3.10 & 3.25 \\
7 & 2.40 & 2.55 & 2.95 \\
8 & 2.75 & 2.90 & 3.05 \\
& 1.75 & 2.15 & 2.60 \\
\multicolumn{4}{c}{ Overall Aspect of Activity }
\end{tabular}

Overall Aspect of Activity
IV V Average Category

$\begin{array}{llll}3.35 & 3.50 & 2.85 & \text { Quite Active }\end{array}$

$\begin{array}{llll}3.10 & 3.15 & 2.71 & \text { Quite Active }\end{array}$

$3.30 \quad 3.40 \quad 3.12 \quad$ Quite Active

$\begin{array}{lll}3.00 & 3.35 & 2.63 \quad \text { Quite Active }\end{array}$

$\begin{array}{lll}3.50 & 3.60 \quad 3.30 \quad \text { Quite Active }\end{array}$

$\begin{array}{llll}3.00 & 3.10 & 2.80 & \text { Quite Active }\end{array}$

$\begin{array}{llll}3.20 & 3.30 & 3.04 & \text { Quite Active }\end{array}$

$2.75 \quad 3.30 \quad 2.51 \quad$ Quite Active

2.87 Active

c. The Description of Student Responses Taught by the Application of the Experiences, Language, Pictures, Symbols and Application (ELPSA) Framework Cooperative Type, Student Teams Achievement Division (STAD)

Complete data on the results of student responses on the application of Experiences, Language, Pictures, Symbols and Application (ELPSA) Frameworks for Cooperative Type, Student Teams Achievement Division (STAD) can be seen Below

Table 4.1 0 . The Category aspects of student responses

\begin{tabular}{cc} 
Average Score & Category \\
\hline $\mathbf{3 . 5 1}$ & Positive \\
\hline
\end{tabular}

Based on the above table, it could be concluded that students' responses to learning with the Application of Experiences, Language, Pictures, Symbols and Application (ELPSA) Frameworks Cooperative Type, Student Teams Achievement Division (STAD) were positive

d. The Description of Student Learning Outcomes Teachable by the Application of the Experience, Language, Pictures, Symbols and Application (ELPSA) Framework Cooperative Setting Type Student Teams Achievement Division (STAD) in Mathematics Learning Material in Class X Students of SMP Negeri 29 Bulukumba

1) Description of Pretest and Posttest

Based on the results of data processing learning outcomes in the experimental class obtained data recapitulation of student mathematics learning outcomes as shown in the following table: 
Tabel 4.11 Summary of Pre-test and Post-test on descriptive statistics in Class X students of SMP Negeri 29 Bulukumba

\begin{tabular}{ccc}
\hline & Pre-test & Post-test \\
\hline Sample Size & 22 & 22 \\
The mean & 31.72 & 81.68 \\
Median & 31 & 81 \\
Mo dus & 28 & 80 \\
Std. Devia si & 6.63 & 5.70 \\
Variant si & 43.92 & 32.51 \\
Skewness & .37 & 0.30 \\
Kurtosis & -0.74 & -0.73 \\
Minimum Score & 22 & 73 \\
Score M aksimum & 45 & 92 \\
Ideal Score & 100 & 100 \\
Range & 23 & 19 \\
\hline
\end{tabular}

The following will be clearer in the categorization of students' abilities in this case the pretest and posttest, as in the following table:

Tabel 4.12 Categories of pre-test and post-test abilities

\begin{tabular}{cccccc}
\hline Interval & $\begin{array}{c}\text { Student ability } \\
\text { categories }\end{array}$ & Frequency & $\begin{array}{c}\text { Pre-test } \\
\text { Percentage } \\
(\%)\end{array}$ & Frequency & $\begin{array}{c}\text { Percentage } \\
(\%)\end{array}$ \\
\hline $90-100$ & Very high & 0 & 0.0 & 3 & 14 \\
$80-89$ & High & 0 & 0.0 & 12 & 54 \\
$65-79$ & Is & 0 & 0.0 & 7 & 32 \\
$55-64$ & Low & 0 & 0.0 & 0 & 0 \\
$0-54$ & Very low & 22 & 100 & 0 & 0 \\
\hline & Total & 22 & 100 & 22 & 100 \\
\hline
\end{tabular}

If related to the Minimum Completeness Criteria (KKM) learning outcomes that applied in SMA Negeri 3 Bulukumba, the students' mathematics learning outcomes before and after being taught with the Application of Experiences, Language, Pictures, Symbols and Application (ELPSA) Framework Cooperative Type, Student Teams Achievement Division (STAD) were grouped into two categories so that frequency and percentage obtained as shown in Table 4.13 . 
Tabel 4.13 Frequency and Percentage of Minimum completeness Criteria (KKM) Learning Outcomes of Pre-test and Post-Test Mathematics for Grade X Students of SMP Negeri 29 Bulukumba

\begin{tabular}{ccccccc}
\multirow{2}{*}{ No } & Score $(\mathrm{KKM})$ & Category & \multicolumn{2}{c}{$\begin{array}{c}\text { Pre-Test } \\
\text { Percentage }\end{array}$} & \multicolumn{2}{c}{$\begin{array}{c}\text { Post_Test } \\
\text { Percentage } \\
\end{array}$} \\
& & Frequency & $(\%)$ & Frequency & $(\%)$ \\
1 & & Complete & 0 & 0 & 19 & 86.36 \\
2 & Not complete & 22 & 100 & 3 & 13.64 \\
& total & & 22 & 100 & 22 & 100
\end{tabular}

Table 4.13 above showed that the percentage of students who were completed in the ability to understand set concepts in mathematics learning was $86.36 \%$ greater than the completeness of $80 \%$.

Based on the description above, it could be concluded that the ability of students in understanding the set concepts in mathematics learning with the Application of Experiences, Language, Pictures, Symbols and Application (ELPSA) CooperativeTypes, Student Teams Achievement Division (STAD) Type were in the effectiveness criteria.

2) Description of Gain Value

The improvement of mathematics learning outcomes for Grade X students of SMP Negeri 29 Bulukumba by using the complete N-Gain. The results of categorizing the N-Gain are presented in Table 4.14..

Tabel 4.14. Students' N-Gain Categorization Results

\begin{tabular}{cccc}
\hline Interval & Category & Frequency & Percentage (\%) \\
\hline $\mathrm{g}<0,3$ & Low & 0 & 0 \\
$0,3 \leq \mathrm{g}<0,7$ & Average & 10 & 45.5 \\
$\mathrm{~g} \geq 0,7$ & High & 12 & 54.5 \\
\hline
\end{tabular}

Based on Table 4.14 it was found that 12 students or $54.5 \%$ were in the high category and 10 students or $45.5 \%$ were in the medium category. However, overall the average $\mathrm{N}$-Gain of student learning outcomes was 0.73 which was in the high category.

1. The Analysis of the Effectiveness of the Application of Experiences, Language, Pictures, Symbols and Application (ELPSA) Framework, Cooperative for Student Teams Achievement Division (STAD) Type in mathematics learning material for students of class X of SMP Negeri 29 Bulukumba

The researcher concluded that the application of Experiences, Language, Pictures, Symbols and Application (ELPSA), Cooperative Type Student Teams Achievement Division (STAD) was able to improve student learning outcomes, where the overall value of students completeness was $80 \%$, and was able to 
provide opportunities for students to be active in learning, and able to make students felt comfortable with positive responses from students.

The following table was the effectiveness of the application of the Experiences, Language, Pictures, Symbols and Application (ELPSA) Framework, Cooperative Type Student Teams Achievement Division (STAD)

Tabel 4.15 The effectiveness of the Experiences, Language, Pictures, Symbols and Application (ELPSA) Framework, Cooperative Type Student Teams Achievement Division (STAD)

\begin{tabular}{|c|c|c|c|c|}
\hline No & Effectiveness Criteria & $\begin{array}{c}\text { Averag } \\
\text { e }\end{array}$ & $\begin{array}{l}\text { Classification/ } \\
\text { Category }\end{array}$ & Conclusion \\
\hline \multirow[t]{4}{*}{1} & Hasil Belajar Siswa & & & \\
\hline & $\begin{array}{l}\text { a. Posttest average score of } \\
\text { more than } 75(\mathrm{KKM})\end{array}$ & 81,68 & High & Fulfilled \\
\hline & $\begin{array}{l}\text { b. Student learning } \\
\text { outcomes gain }\end{array}$ & 0,73 & High & Fulfilled \\
\hline & $\begin{array}{l}\text { c. Classical completeness } \\
\text { equal to or more than } \\
80 \%\end{array}$ & $86,36 \%$ & & Fulfilled \\
\hline 2 & Student activities & 2,87 & Quite Active & Fulfilled \\
\hline 3 & Student responses & 3,51 & Positive & Fulfilled \\
\hline
\end{tabular}

Based on Table 4.15, it appeared that the level of learning effectiveness for each indicator of learning effectiveness had been fulfilled and the score for overall learning was 3.14, or was in the category of effective. Thus the application of the Experiences, Language, Pictures, Symbols and Application (ELPSA) Framework for the Cooperative Type, Student Teams Achievement Division (STAD) in mathematics learning was effective to be applied to class $\mathrm{X}$ students of SMP Negeri 29 Bulukumba.

\section{Results of Inferential Analysis}

a. Data Normality Test

Testing of the increase of students mathematics learning before applying Experiences, Language, Pictures, Symbols and Application (ELPSA) Framework, Cooperative Type of Student Teams Achievement Division (STAD). The results of students' mathematics learning after application of the Experiences, Language, Pictures, Symbols and Application (ELPSA) Framework Cooperative Type, Student Teams Achievement Division (STAD) should be tested on data normality first. . To find out the pre-test, post-test and gain data, normal or not, the ShapiroWilk test was used in the SPSS 20.0 for Windows program with a significance level of 0.05 .

Based on the Shapiro-Wilk normality test, the significance or P-value for pre-test $=0.342$, the significance of $\mathrm{P}$ - value for post-test $=0.373$ and the significance of $\mathrm{P}$ - value for gain $=0.123$ of 22 students. Because $\mathrm{P}$ - value pretest $=0.342>\alpha=(0.05), \mathrm{P}$ - value post-test $=0.373>\alpha=(0.05)$, and $\mathrm{P}$ - value gain 
$=0.123>\alpha=(0.05)$. This meant that the data come from normally distributed populations.

b. T-test

The results of testing the hypothesis are as follows:

1. Testing the average score of student learning outcomes ( post-test) after being taught by the Experiences, Language, Pictures, Symbols and Application (ELPSA) Framework Cooperative Type Student Teams Achievement Division (STAD) greater than $74.9(\mathrm{KKM}=75)$ was conducted using a test one sample test. It appeared that the p value ( sig. (2-tailed) ) was $0.001<\alpha=(0.05)$, indicated that the average student mathematics learning outcomes after being taught with the application of the Experiences, Language, Pictures, Symbols and Application (ELPSA), Cooperative Type Student Teams Achievement Division (STAD) more than 74.9. This meant that $\mathrm{H}_{0}$ was rejected and $\mathrm{H}_{1}$ accepted at an average of learning outcomes (post-test) with the implementation of the Experiences, Language, Pictures, Symbols and Application (ELPSA) Framework, Cooperative Type Student Teams Achievement Division (STAD) over KKM.

2. The average test of normalized gain results in the experimental class was conducted by one sample test. The value of $p$ ( sig. (2-tailed) ) was $0.001<\alpha$ $=(0.05)$, this meant that $\mathrm{H}_{0}$ was rejected and $\mathrm{H}_{1}$ accepted. Showed that the average of increase in student learning outcomes (normalized gain) with the application of the Experiences, Language, Pictures, Symbols and Application (ELPSA), Cooperative Type Student Teams Achievement Division (STAD) was more than 0.29.

\section{Analisis keefektifan Effectiveness analysis}

The effectiveness analysis was intended to find out whether the hypothesis was verified. the major hypothesis formulated was the application of the Experiences, Language, Pictures, Symbols and Application (ELPSA) Framework for Cooperative Setting Type of Student Teams Achievement Division (STAD) in mathematics learning effectively applied to students of class X SMP Negeri 29 Bulukumba". The major hypothesis above is said to be proven true if all minor hypotheses are also tested true. The results of the minor hypothesis analysis are as follows.

\section{a. Minimum completeness Criteria}

The completeness of students learning outcomes of class X SMP Negeri 29 Bulukumba after being taught with the application of Experiences, Language, Pictures, Symbols and Application (ELPSA), Cooperative Settings for Student Teams Achievement Division (STAD) Type was greater than $80 \%$.

Based on table 4.13 it could be seen that the frequency of students who had scored more than was 19 people or if it was presented the results were $86.36 \%$. This was in accordance with the category, namely completeness student learning outcomes were greater than $80 \%$. 


\section{b. Student activities}

The average score of student activity the application of Experiences, Language, Pictures, Symbols and Application (ELPSA) Framework, Cooperative Type Student Teams Achievement Division (STAD) in the class X SMP Negeri 29 Bulukumba was equal to or greater than 2.5 or was in the category enough active.

Based on the results of descriptive analysis, the average score of class $\mathrm{X}$ student activities taught through the application of Experiences, Language, Pictures, Symbols and Application (ELPSA) Cooperative Type Student Teams Achievement Division (STAD) was in accordance with the category, namely 2.87 and were in the quite active category.

\section{c. Student Responses}

The average score of student responses after being taught with the application of the Experiences, Language, Pictures, Symbols and Application (ELPSA) Framework for Cooperative Type Student Teams Achievement Division (STAD) in class X of SMP Negeri 29 Bulukumba was equal or greater than 3.5

Based on the results of the descriptive analysis, the average score of the students of SMP Negeri 29 Bulukumba was taught through the application of the Experiences, Language, Pictures, Symbols and Application (ELPSA), Cooperative Type Student Teams Achievement Division (STAD) was in accordance with the category, namely 3,51 and were in the positive category.

\section{Discussion}

\section{a. Implementation of Learning}

Overall, the application of the Experiences, Language, Pictures, Symbols and Application (ELPSA) Framework for the Cooperative Setting Type Student Teams Achievement Division (STAD) in mathematics learning material for class X student at SMP Negeri 29 Bulukumba could improve students' ability to understand set material, this shown by the normalized gain classification that the majority of students were in the high category. This learning was also able to increase student activity in learning and provide broad opportunities for students to interact with the teacher directly, in terms of conveying their experiences related to the set material learned through responses, questions, complaints or problems faced by students about the material set in daily life -day.

The characteristics of ELPSA made it easy for students to understand the concepts of the material being studied because each concept was always associated with experiences, objects / images related to daily life that students can imagine. Where the concept is meaningful if it is built and related to one's life experience. Therefore, linking learning with students' life experiences at the beginning of learning allowed students to get to know concepts in a meaningful way.

It was in line with Lowrie (2014) that a sequence of special events occurs in the formation of concepts that lead to understanding where experience is the initial sequence. Another view put forward by Freudenthal (1991) states that mathematics is a human activity that views students not as passive recipients of ready-made mathematics. But he must be given the opportunity to rediscover 
mathematics under the guidance of the teacher (Gravemeijer, 1994). So that it could be concluded that linking learning with the experiences that had been owned by students at the beginning of learning can make learning more meaningful, so students interpreted new knowledge with existing knowledge.

The observation results of the application of Experiences, Languages, Pictures, Symbols and Application (ELPSA) in learning mathematics in STAD type cooperative settings showed an increase in each meeting because this was at the end of each meeting the teacher (researcher) saw the observation data of each meeting so that it was possible to improve the implementation learning at the next meeting.

When the learning process took place, the teacher presented the material using teaching aids to provide experience to students in recognizing the concept of collections in the form of images or objects that were around the school, this was in line with the opinion of Dienes who states that that concrete representations and teaching aids can used to help students learn abstract ideas (Lowrie \& Patahudin, 2015: 96).

In addition, during the learning process the teacher asks students to discuss problems or questions in the worksheets that had been shared and explained the concepts with their own sentences, but in this phase the teacher had difficulty monitoring the course of the discussion (providing guidance to students). That was because students were still not accustomed to learning independently and expressing ideas individually. Students in general, always expected teacher explanations related to the material without any effort to understand the material through reading the students' books provided, but the subsequent meetings students could adapt on the class.

Based on the description above it could be concluded that the implementation of the Experiences, Language, Pictures, Symbols and Application (ELPSA) Framework, Cooperative Type Student Teams Achievement Division (STAD) in mathematics learning material was well implemented. This result was based on the average feasibility of the learning model from the first meeting to the fifth meeting of 3.71 or was in the well-implemented category.

\section{b. Student Activity}

The results of observations on student activities in the application of the Experiences, Language, Pictures, Symbols and Application (ELPSA) Framework, Cooperative Setting Type Student Teams Achievement Division (STAD) in mathematics learning material for the class $X$ students of SMP Negeri 29 Bulukumba showed that the average of the eight categories observed to be in the active category. Each aspect of student activity was expected to be achieved, and always increased from previous meetings although on average each aspect of the whole meeting was different but all aspects in the category are quite active.

The aspects of interacting, discussing, collaborating with friends in solving problems in the worksheets were the highest average aspects of the whole 
meeting, namely 3.30 active categories. This was also reinforced by the opinion of Hulten and De Vries (in Slavin, 2005) which suggests that cooperative learning makes group members excited. The same thing was also stated by Vygostky (Trianto, 2011: 30) that the learning process will occur through collaboration between individuals through discussion or in other words emphasizing social interaction and constructing knowledge from the social environment.

From the explanation above, the conclusion could be drawn that the application of the Experiences, Language, Pictures, Symbols and Application (ELPSA) Framework for the Cooperative Type Student Teams Achievement Division (STAD) in mathematics learning material for class $\mathrm{X}$ student at SMP Negeri 29 Bulukumba could make student learning activities active in where students constructed their own way of understanding things through individual thought processes and social interactions with other people (groups).

\section{c. Student Response}

Positive student responses to learning were also taken into account in determining the quality of learning. Student response data obtained from the results of the questionnaire responses given to all students after the application of the Experiences, Language, Pictures, Symbols and Application (ELPSA) Framework for Cooperative Type Student Teams Achievement Division (STAD) in mathematics learning material for class X students of SMP Negeri 29 Bulukumba ended up. From the results of the student response questionnaire showed that there were 15 students or $68.18 \%$ of students who gave positive responses and 7 students or $31.82 \%$ who gave responses that tended to be positive. This showed that on average all students responded positively to the Experiences, Language, Pictures, Symbols and Application (ELPSA) Framework for Cooperative Type Student Teams Achievement Division (STAD).

\section{d. Student learning outcomes}

Based on the score pretest obtained before applying the Experiences, Language, Pictures, Symbols and Application (ELPSA) Framework for Cooperative Type of Student Teams Achievement Division (STAD) on mathematics learning materials set class X students of SMP Negeri 29 Bulukumba indicated that the level of prior knowledge of students remained at a very low stage with an average of 31.72 where none of the students completed the categorization based on the KKM score. The maximum score obtained by students was 45 from an ideal score of 100.

However, the average student learning outcomes after being taught with the application of the Experiences, Language, Pictures, Symbols and Application (ELPSA) Framework for Cooperative Type Student Teams Achievement Division (STAD) in mathematics learning material for class $\mathrm{X}$ students of SMP Negeri 29 Bulukumba were at high category with an average of 81.68. The maximum score of 92 from the ideal score of 100 and classical completeness was greater than $80 \%$, that was $86.36 \%$. 
The results of students' mathematics learning also showed that there was a significant increase after the implementation of the Experiences, Language, Pictures, Symbols and Application (ELPSA) Framework for Cooperative Type Student Teams Achievement Division (STAD) on the set of mathematical learning materials class X students of SMP Negeri 29 Bulukumba. This indicated from the value of the gain obtained by students namely 0.73 which was in the high category. The increase was inseparable from the complexity of learning with the application of the Experiences, Language, Pictures, Symbols and Application (ELPSA) Framework for Cooperative Setting Type Student Teams Achievement Division (STAD).

\section{CONCLUSIONS AND SUGGESTION}

The conclusion that could be drawn from this research was learning using the application of Experiences, Language, Pictures, Symbols and Application (ELPSA) Frameworks for Cooperative Setting Type Student Teams Achievement Division (STAD) in mathematics learning material was effective to be applied to students in class X SMP Negeri 29 Bulukumba based on criteria: 1) the outcomes of class X students of SMP Negeri 29 Bulukumba after being taught through the application of the Experiences, Language, Pictures, Symbols and Application (ELPSA) Framework for Cooperative Type Student Teams Achievement Division (STAD) in learning mathematics the set material reached 81, 68 was greater than $74.9(\mathrm{KKM}$ value $=75)$ and was in the high category. 2) the average of increase in student learning outcomes, namely the average post-test score was higher than the average score of the pretest which was described in the form of normalized gain exceeded $0.29,0.73$ was in the high category. 3) the completeness of student learning outcomes by using Experiences, Language, Pictures, Symbols and Application (ELPSA) Framework for Cooperative Type of Student Teams Achievement Division (STAD) in mathematics learning material set in the class X students of SMP Negeri 29 Bulukumba was classically greater than $80 \%$ is $86.36 \%$.4) the average score of student activity in the learning Experiences, Language, Pictures, Symbols and Application (ELPSA) Framework for Cooperative Type of Student Teams Achievement Division (STAD) in mathematics learning material set in class $X$ students of SMP Negeri 29 Bulukumba obtained value of 2, 87 and were in the active category. 5) The average score of students' responses to learning through the application of the Experiences, Language, Pictures, Symbols and Application (ELPSA) Framework for Cooperative Type of Student Teams Achievement Division (STAD) in mathematics learning set material for grade class X students of SMP Negeri 29 Bulukumba was 3.51 and were in the positive category .

\section{Suggestion}

Based on the results of research that had been achieved as for the suggestions proposed by the author is that there was a further need to be 
conducted on Experiences, Language, Pictures, Symbols and Applications (ELPSA), where each component in ELPSA although defined separately but in its implementation was a unity in learning, both in the field of mathematics studies and other fields of study, because the components in ELPSA could be implemented in other fields of study using the same learning model or with variations in other learning models.

\section{REFERENCES}

Abdurrahman. 1994. Pengelolaan pengajaran. Ujung Pandang. CV. Bintang Selatan.

Ardin. 2015. Keefektifan Pembelajaran dengan pendekatan pembelajaran Matematika Realistik Setting Kooperatif Tipe NHT Pada Materi Pokok Ruang Dimensi Tiga siswa Kelas X SMAN 1 Kulisusu. Tesis tidak diterbitkan: PPS UNM

Arends, Richard I. (2008) Learning to Teach: Belajar untuk Mengajar. Buku Dua. (Penterjemah: Helly Prayitno Soetjipto dan Sri Mulyantini Soetjipto). Yogyakarta: Pustaka Pelajar.

Aziz, Abdullah. 2007. Metode Dan Model-Model Mengajar. Bandung: Alfabeta

Dimyanti \& Mujiono. 2009. Belajar dan Pembelajaran. Jakarta. PT. Rineka Cipta.

Djamarah, Syaiful Bahri dan Azwan zain. 2002. Strategi Belajar Mengajar. Jakarta : PT Rineka Cipta.

Direktorat Jendral Pendidikan Dasar dan Menengah Departemen Pendidikan Nasional (2003). Undang-undang Republik Indonesia No. 20 Tahun 2003, Tentang Sistem Pendidikan Nasional, Jakarta :Direktorat Jendral Pendidikan Dasar dan Menengah Departemen Pendidikan Nasional.

Fathurrohman, Pupuh dan Sobry Sutikno. 2011. Strategi Belajar Mengajar. Bandung. PT. Refika Aditama.

Gravemeijer. 1994. Developing Realistic Mathematics Education. Feudhenthal Institute : Utrecht

Gravemeijer. 2010. Creating opportunities for students to reinvent mathematics. Netherlands. Freudenthal Institute and Department of Educational Research, Utrecht University.

Haling. Abdul. 2007. Belajar dan Pembelajaran. Makassar: Badan Penerbit Universitas Negeri Makassar

Hasanuddin. 2010 . Keefektifan model pembelajaran berdasarkan teori konstruktivisme pada pembelajaran matematika d SMPN 15 makassar. Tesis tidak diterbitkan: PPS UNM

Hasmiati. 2013. Efektifitas Pembelajaran Matematika Realistik dengan setting Kooperatif tipe TEAM dan tipq $\$$ GGT materi volume bangun ruang pada kelas V SD Inpres Bakung II. Tesis tidak diterbitkan . Makassar : PPs UNM.

Huda, Miftahul. 2012. Cooperatif Learning. Cetakan II. Pustaka Pelajar. Yogyakarta

Hudojo, Herman. 1990. Strategi Mengajar Belajar Matematika. Malanga: ikip malang. 
Hudojo, Herman. 2001. Pengembangan Kurikulum dan Pembelajaran Matematika. Malang: Universitas Negeri Malang.

Ibrahim, Muslimin. 2000. Pembelajaran Kooperatif. Universitas Negeri Surabaya.

Ibrahim dan Suparni. 2008. Strategi Pembelajaran Matematika. Yogyakarta: Sukses Offset.

Jihad, Asep.Haris, Abdul. 2012. EvaluasiPembelajaran. Jakarta : Multi Pressindo.

Keswara, R. 2013. Pembelajaran Matematika di Indonesia Masuk Peringkat Rendah

(online).(http://nasional.sindonews.com/read/804091/15/pembelajaranmatematika-di-indonesia-masuk-peringkat-rendah-1384111047).(diakses tanggal 5 November 2015).

Lowrie \& Patahuddin. 2015. ELPSA-Kerangka Kerja Pengembangan Pembelajaran Matematika. Australia Government. Departement of Foreign Affairs and Trade.

Muhfidah. 2008. Model-model Pembelajaran. (Online).(Http//www.muhfidah.com). Diakses tanggal 20 November 2015.

Nuharini, Dewi, dk. 2008. Matematika Konsep dan Aplikasinya Untuk SMP/MTs Kelas VII. Pusat Perbukuan Departemen Pendidikan Nasiona. Jakarta

Nur, M. 2000. Model Pembelajaran Kooperatif. Surabaya.UNESA

Nur Asma. 2006. Model Pembelajaran Kooperatif. Jakarta: Departemen Pendidikan Nasional.

Nurdin. 2007. Model Pembelajaran Matematika yang Menumbuhkan Kemampuan Metakognitif untuk Menguasai Bahan Ajar. Disertasi. Tidak diterbitkan. Surabaya: PPs UNESA.

Padmono. 2002. Evaluasi dan Pengajaran. Surakarta: FKIP UNS.

Raehana, Sitti. 2013. Pengaruh Regulasi Diri, Motivasi Berprestasi, Iklim Keluarga, dan Efikasi Diri terhadap Prestasi Belajar Matematika Siswa Kelas X SMK Negeri di Kota Makassar. Tesis. Tidak diterbitkan. Makassar: Univeristas Negeri Makassar.

Rahmawati, N. 2012. Tingkat Prestasi Dan Efikasi Diri Siswa Ditinjau dari Penerapan Program Imersi. Yogyakarta: Tesis Fakultas Psikologi Universitas Gadjah Mada.

Risal, Nur Alam. 2009. Efektifitas Pembelajaran Matematika Berbasis Pendekatan Realistik. Makassar: Skripsi FMIPA UNM.

Ruseffendi, E.T. 1998. Pengantar kepada Membantu Guru Mengembangkan Kompetensinya dalam Pendidikan Matematika untuk Meningkatkan CBSA. Bandung: Tarsito.

Sagala, Syaiful, 2003. Konsep dan Makna Pembelajaran. Bandung: CV ALFABETA

Sagala, Syaiful. 2011. Konsep dan Makna Pembelajaran. Bandung: Penerbit Alfabeta

Sahabuddin. 2007. Mengajar dan Belajar. Makassar: Badan Penerbit UNM. 
Slamet, dkk. 2001. Manajemen peningkatan mutu berbasis sekolah. Depdiknas, Direjen pendidikan dasar dan menengah dierktorat SLTP.

Slameto, 2010. Belajar dan Faktor-Faktor yang Mempengaruhinya. Jakarta: Rineka Cipta

Sanjaya, Wina. 2006. Strategi Pembelajaran Berorientasi Standar Proses Pendidikan. Jakarta: Kencana Preana Media Group

Sardiman, 2011. Interaksi dan Motivasi Belajar mengajar. Jakarta: PT. Raja Grafindo Persada.

Slavin, Robert E. 2005. Cooperative Learning: Theory, Research, and Practice $2^{\text {nd }}$ Edition. Massachusetts: Allyn and Bacon.

Slavin, R. 2010. Cooperative Learning: Theory, Research ang Practice. Englewood Cliff, NJ: Prentice Hall.

Soedjadi. 2000. Kiat Pendidikan Matematika di Indonesia. Departemen Pendidikan Nasional

Soffa, Muhammad. 2008. Meningkatkan Hasil Belajar Matematika Melalui Pembelajaran Kooperatif dengan Pendekatan Tipe STAD di SMA Muhammadiyah I Nganjuk tahun 2008/2009. (http://muchammadsoffa1.blogspot.com/2009_05_01_archive.html. (diakses tanggal 3 November 2015).

Sudjana, Nana. 1989. Penilaian Hasil Belajar. Jakarta : Bumi aksara

Sudjanna, Nana. 2004. Penilaian Hasil Proses Belajar Mengajar. Bandung: Remaja Rosda Karya.

Sudjana, Nana \& Ibrahim. 2011. Penelitian dan Penilaian Pendidikan. Bandung : Sinar Baru Algesindo

Sugiyono. 2013. Metode Penelitian Pendidikan Pendekatan Kuantitatif, Kualitatif, dan R\&D. Bandung: Alfabeta.

Suherman. 2001. Strategi Pembelajaran Matematika. Bandung JIC. UPI.

Suprijono, Agus. 2009. Cooperative Learning. Surabaya: Pustaka Belajar.

Susanto, A. 2013. Teori Belajar Pembelajaran di Sekolah Dasar. Jakarta. Kencana Prenada Media Group

Syah, Muhibbin. 2011. Psikologi Belajar. Jakarta: PT Rajagrafindo Persada

Tim Penyusun Kamus Pusat Pembinaan dan Pengembangan Bahasa. 2006. Kamus Besar Indonesia. Jakarta: Balai Pustaka.

Tiro, M A, Arbianingsih. 2011. Teknik Pengambilan Sampel. Makassar: Andira Publisher.

Tiro Muhammad Arif, 2007. Dasar-Dasar Statistika. Edisi kedelapan. Makassar. Badan Penerbit Universitas Negeri Makassar.

Trianto. 2008. Model-model Pembelajaran Inovatif Berorientasi Kontruktivistik. Jakarta: Prestasi Pustaka Publisher.

Trianto. 2011. Mendesain Model Pembelajaran Inovatif Progresif. Jakarta: Kencana Prenada.

Uno, Hamzah. B. 2006. Perencanaan Pembelajaran. Jakarta : PT. Bumi Aksara.

Usman, M.U dan Setiawati. 2001. Upaya optimalisasi Kegiatan Belajar mengajar. Bandung : Rosdikarya

Wijaya,A. 2014. Pengenalan Desain Pembelajaran ELPSA (Experience, Language, Picture, Symbols, Application. Pusat Pengembangan dan 
DAYA MATEMATIS : Jurnal Inovasi Pendidikan Matematika, Volume 8 No. 1 Maret 2020

Pemberdayaan Pendidikan dan Tenaga Kependidikan (PPPPTK) Matematika.

Winkel, W.S. 2009. Psikologi pengajaran. Yogyakarta: Media Abadi 